Jurnal Cendekia Akuntansi

\title{
ANALISIS EFEKTIVITAS PROGRAM PEMUTIHAN, TINGKAT KEPATUHAN PEMBAYARAN PAJAK, DAN LAYANAN SAMSAT KELILING TERHADAP PENINGKATAN PENERIMAAN PAJAK KENDARAAN BERMOTOR
}

\author{
Putri Awalina \\ Astri Dian Puspitasari \\ Universitas Islam Kadiri \\ E-mail: putriawalina@uniska-kediri.ac.id
}

\begin{abstract}
Abstrak
Penelitian ini bertujuan untuk mengetahui Pengaruh Efektivitas Program Pemutihan, Kepatuhan Wajib Pajak dalam Membayar Pajak Kendaraan Bermotor, dan Layanan Samsat Keliling terhadap Peningkatan Penerimaan Pajak Kendaraan Bermotor. Penelitian ini dilakukan di Kantor Bersama Samsat Kediri Kota. Jumlah data yang digunakan sebanyak 59 data. Metode pengambilan sampel yang digunakan metode accidental sampling. Teknik analisis data yang digunakan dalam penelitian ini adalah regresi linier berganda dengan menggunakan program software SPSS versi 24. Berdasarkan hasil analisis uji t diketahui bahwa variabel efektivitas program pemutihan dan variabel kepatuhan Wajib Pajak dalam membayar Pajak berpengaruh positif terhadap peningkatan Pajak Kendaraan Bermotor pada Kantor Bersama Samsat Kediri Kota dengan nilai $\mathrm{T}_{\text {hitung }}$ efektivitas program pemutihan $\left(\mathrm{X}_{1}\right)$ 2,980 lebih besar dari $\mathrm{T}_{\text {tabel }}$ 2,001 dan nilai $\mathrm{T}_{\text {hitung }}$ kepatuhan Wajib Pajak $\left(\mathrm{X}_{2}\right)$ 2,370 lebih besar dari $\mathrm{T}_{\text {tabel }}$ 2,001. Sedangkan berdasarkan uji $\mathrm{F}$ diketahui bahwa variabel efektivitas program pemutihan, tingkat kepatuhan pembayaran pajak, dan layanan Samsat Keliling berpengaruh terhadap peningkatan penerimaan Pajak Kendaraan Bermotor.
\end{abstract}

\section{Kata Kunci : Pemutihan, Kepatuhan Pembayaran, Samsat Keliling, Pajak} Kendaraan Bermotor.

\section{Abstract}

This study aims to determine the Effect of Bleaching Program Effectiveness, Taxpayer Compliance in Paying Motor Vehicle Taxes, and Mobile Samsat Services on Increasing Motor Vehicle Tax Revenues. This research was conducted at the Kediri Kota Samsat Joint Office. The amount of data used was 
59 data. The sampling method used was accidental sampling method. The data analysis technique used in this study is multiple linear regression using the SPSS version 24 software program. Based on the results of the t test analysis, it is known that the effectiveness of the bleaching program and the taxpayer compliance variable in paying taxes has a positive effect on the increase in Motor Vehicle Tax at the Samsat Joint Office. Kediri Kota with the value of T-count the effectiveness of the bleaching program $\left(X_{1}\right)$ 2,980 is greater than T-table 2,001 and the T-count value of taxpayer compliance $\left(X_{2}\right)$ 2,370 is greater than T-table 2,001 Meanwhile, based on the F test, it is known that the effectiveness of the bleaching program, the level of tax payment compliance, and the Mobile Samsat service have an effect on the increase in Motor Vehicle Tax revenue.

Keywords : Bleaching, Payment Compliance, Mobile Samsat, Motor Vehicle Tax.

\section{PENDAHULUAN}

Upaya Pemerintah Provinsi Jawa Timur dalam meningkatkan penerimaan dari sektor pajak terus digalakkan agar target penerimaan Pajak Daerah dapat tercapai. Dalam memaksimalkan penerimaan Pajak Kendaraan Bermotor, ada beberapa upaya antara lain penyelenggaraan program pemutihan, peningkatan kepatuhan Wajib Pajak, dan Layanan Samsat Keliling. Pemutihan merupakan program yang diagendakan oleh Pemerintah Daerah dalam rangka meringankan Wajib Pajak dalam pengurusan pembebasan pokok BBNKB atas penyerahan kedua dan seterusnya dan pembebasan sanksi administratif PKB.

Peningkatan jumlah kendaraan dari tahun ke tahun menjadi suatu upaya pembenahan dalam meningkatkan Pendapatan Asli Daerah (PAD), namun dalam upaya tersebut terdapat kendala dimana kurangnya kepatuhan Wajib Pajak dalam memenuhi kewajibannya yang mengakibatkan jumlah tunggakan Pajak Kendaraan Bermotor semakin meningkat. Kepatuhan Wajib Pajak merupakan perilaku Wajib Pajak yang taat dalam memenuhi dan melaksanakan kewajiban perpajakannya sesuai dengan peraturan perundang-undangan yang berlaku. Untuk itu Pemerintah Daerah diharapkan mampu menekan jumlah tunggakan pajak dengan program tertentu yang ditetapkan oleh Pemerintah Provinsi atau Pemerintah Pusat maupun dengan meningkatkan kualitas pelayanan. Peningkatan kualitas pelayanan Kantor Bersama Samsat dapat dilakukan dengan membentuk unit pembantu misalnya Samsat Keliling. Samsat Keliling adalah layanan pengesahan STNK setiap tahun, pembayaran PKB dan SWDKLLJ dengan mendatangi daerah tertentu yang kurang dijangkau oleh Wajib Pajak ataupun dari pusat pelayanan samsat induk.

Ketiga upaya tersebut diharapkan dapat mendorong Wajib Pajak untuk melaksanakan kewajiban perpajakannya serta memaksimalkan penerimaan Pajak Kendaraan Bermotor. Penelitian ini bertujuan untuk mengetahui pengaruh efektivitas program pemutihan, tingkat kepatuhan pembayaran pajak, dan layanan Samsat Keliling terhadap peningkatan penerimaan Pajak Kendaraan Bermotor. 


\section{TINJAUAN PUSTAKA}

\section{Program Pemutihan}

Menurut Peraturan Gubernur No. 55 Tahun 2019 tentang Pembebasan Pajak Daerah untuk Rakyat Jawa Timur Tahun 2019, (2019) mengenai pembebasan pokok Bea Balik Nama Kendaraan Bermotor atas penyerahan kedua dan seterusnya dan pembebasan sanksi administratif Pajak Kendaraan Bermotor dan Bea Balik Nama Kendaraan Bermotor (pemutihan).

\section{Efektivitas}

Menurut Mahmudi (2015), Efektivitas merupakan hubungan antara output dengan tujuan. Semakin besar kontribusi output terhadap pencapaian tujuan, maka semakin efektif organisasi, program atau kegiatan. Suatu organisasi program atau kegiatan dinilai efektif apabila output yang dihasilkan bisa memenuhi tujuan yang diharapkan.

\section{Kepatuhan}

Menurut Keputusan Menteri Keuangan No. 544/KMK.04/2000, kepatuhan Wajib Pajak yaitu suatu tindakan Wajib Pajak untuk memenuhi kewajiban perpajakannya sesuai dengan peraturan perundang-undangan dan peraturan pelaksanaan perpajakan yang berlaku di suatu Negara.

\section{Layanan Samsat Keliling}

Menurut Peraturan Presiden Republik Indonesia Nomor 5 Tahun 2015 Tentang Penyelenggaraan Sistem Administrasi Manunggal Satu Atap Kendaraan Bermotor (2015), Layanan Samsat Keliling adalah inovasi layanan publik yang berupa layanan pengesahan STNK setiap tahun, pembayaran (PKB) dan (SWDKLLJ) dengan mendatangi daerah tertentu yang kurang dijangkau oleh Wajib Pajak ataupun dari pusat pelayanan Samsat Induk.

\section{Hipotesis}

Berdasarkan uraian diatas, maka hipotesis yang dapat diajukan adalah

$\mathrm{H}_{1}$ : Diduga ada pengaruh yang signifikan antara Efektivitas Program Pemutihan terhadap Peningkatan Penerimaan Pajak Kendaraan Bermotor secara parsial.

$\mathrm{H}_{2}$ : Diduga ada pengaruh yang signifikan antara Tingkat Kepatuhan Pembayaran Pajak terhadap Peningkatan Penerimaan Pajak Kendaraan Bermotor secara parsial

$\mathrm{H}_{3}$ : Diduga ada pengaruh yang signifikan antara Layanan Samsat Keliling terhadap Peningkatan Penerimaan Pajak Kendaraan Bermotor secara parsial

$\mathrm{H}_{4}$ : Diduga ada pengaruh yang signifikan antara Efektivitas Program Pemutihan, Tingkat Kepatuhan Pembayaran Pajak, dan Layanan Samsat Keliling terhadap Peningkatan Penerimaan Pajak Kendaraan Bermotor secara simultan.

\section{METODE PENELITIAN}

Penelitian ini menggunakan jenis penelitian deskriptif dengan pendekatan kuantitatif. Populasi dalam penelitian ini adalah seluruh penerimaan Pajak Kendaraan Bermotor yang diterima oleh Kantor Bersama Samsat Kediri Kota dan 
seluruh Wajib Pajak Kendaraan Bermotor yang terdaftar di Kantor Bersama Samsat Kediri Kota. Sedangkan sampel dalam penelitian ini adalah jumlah target dan realisasi penerimaan Pajak Kendaraan Bermotor pada tahun 2015-2019, dan Wajib Pajak Kendaraan Bermotor yang menjadi sampel penelitian yaitu 59 data/responden.

\section{Teknik Analisis}

Uji Kualitas Data

a. Uji Validitas

Validitas adalah pengukuran yang menunjukkan tingkat ketepatan (kesahihan) ukuran suatu instrument terhadap konsep yang diteliti. Teknik uji validitas item dengan korelasi Pearson, yaitu dengan cara mengorelasikan skor item dengan skor total item tiap variabel. Apabila nilai Signifikansi $<0,05$ maka dapat disimpulkan bahwa data tersebut valid.

b. Uji Reliabilitas

Reliabilitas adalah sejauh mana pengukuran dari suatu tes tetap konsisten setelah dilakukan berulang-ulang terhadap subjek dan dalam kondisi yang sama. Pada program SPSS, metode ini dilakukan dengan metode Cronbach Alpha, dimana kuesioner dikatakan reliabel jika nilai Cronbach Alpha >0,60.

\section{Uji Asumsi Klasik}

a. Uji Normalitas

Uji normalitas data bertujuan untuk mengukur apakah di dalam model regresi linier berganda variabel independen dan variabel dependen keduanya mempunyai distribusi normal atau mendekati normal.

b. Uji Multikolinieritas

Multikolinearitas adalah keadaan pada model regresi ditemukan adanya korelasi yang sempurna atau mendekati sempurna antar variabel independen.

c. Uji Heteroskedastisitas

Heteroskedastisitas adalah keadaan di mana dalam model regresi terjadi ketidaksamaan varian dari residual pada satu pengamatan ke pengamatan yang lain.

d. Uji Autokorelasi

Uji Autokorelasi digunakan untuk mengetahui ada atau tidaknya penyimpangan asumsi klasik autokorelasi yaitu korelasi yang terjadi antara residual pada satu pengamatan lain pada model regresi. 


\section{Analisis Regresi Linier Berganda}

Analisis regresi linier berganda adalah analisis untuk mengetahui ada tidaknya pengaruh yang signifikan secara parsial atau simultan antara dua atau lebih variabel independen terhadap satu variabel dependen.

$$
\mathrm{Y}=\mathrm{a}+b_{1} \mathrm{X}_{1}+b_{2} \mathrm{X}_{2}+b_{3} \mathrm{X}_{3}+b_{1} \mathrm{X}_{2} \mathrm{X}_{2} \mathrm{X}_{2}+\mathrm{e}
$$

\section{Uji T}

Uji hipotesis yang digunakan dalam penelitian ini yaitu Uji Parsial (Uji T). Ghozali (2018: 88) uji t digunakan untuk menguji pengaruh masing-masing variabel independen yang digunakan dalam penelitian ini terhadap variabel dependen secara parsial.

\section{Uji F}

Menurut Ghozali (2016:96) Uji F pada dasarnya menunjukkan apakah semua variabel independen atau bebas yang dimasukkan dalam model mempunyai pengaruh secara bersama-sama terhadap variabel dependen atau terikat.

\section{HASIL PENELITIAN \\ Uji Kualitas Data}

Uji Validitas

Valid tidaknya kuesioner dapat diketahui apabila korelasi antara masingmasing item terhadap total skor variabel menunjukkan hasil penelitian $<0,01$ atau 0,05 berarti angka probabilitas tersebut signifikan, sehingga dapat disimpulkan bahwa masing-masing item pertanyaan adalah valid.

\section{Uji Reliabilitas}

Reliabilitas data adalah indeks yang menunjukkan sejauh mana sesuatu alat pengukur dipakai 2 kali untuk mengukur yang diperoleh relatif sama dan hasil pengukuran yang diperoleh relatif konsisten, maka alat ukur tersebut reliabel

\begin{tabular}{|c|c|c|}
\hline Variabel & $\begin{array}{c}\text { Cronbach's } \\
\text { Alpha }\end{array}$ & Keterangan \\
\hline Kepatuhan & 0,901 & Reliabel \\
Pembayaran & & \\
Pajak $\left(\mathrm{X}_{2}\right)$ & & \\
\hline Layanan & 0,877 & Reliabel \\
Samsat & & \\
Keliling $\left(\mathrm{X}_{3}\right)$ & & \\
\hline
\end{tabular}

Berdasarkan tabel di atas diketahui melalui nilai Cronbach's Alpha dimana nilai variabel $\mathrm{X}_{2}$ dan $\mathrm{X}_{3}$ berada lebih besar dari 0,6. Dengan demikian, seluruh variabel dapat dikatakan reliabel. 


\section{Uji Asumsi Klasik}

a.Uji Normalitas

Hasil penelitian uji normalitas didapatkan nilai signifikansi sebagai berikut :

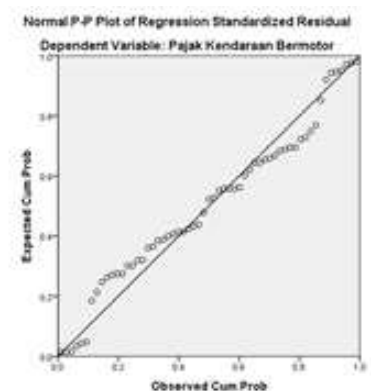

Sumber: Data diolah peneliti, 2020

Sebaran titik-titik dari gambar Normal P-P Plot di atas relatif mengikuti dan berada pada garis diagonal, sehingga dapat disimpulkan bahwa (data) residual terdistribusi normal.

b. Uji Multikolinieritas

Uji Multikoliniearitas bertujuan untuk menguji apakah model regresi ditemukan adanya korelasi antara variabel bebas (independen).

\begin{tabular}{|c|l|r|r|}
\hline \multicolumn{3}{|c|}{ Coefficients $^{\mathbf{n}}$} \\
\cline { 3 - 4 } \multicolumn{2}{|c|}{ Model } & \multicolumn{2}{|c|}{ Collinearity Statistics } \\
\cline { 3 - 4 } 1 & Tolerance & VIF \\
\cline { 2 - 4 } & (Constant) & & \\
\cline { 2 - 4 } & Program Pemutihan & .972 & 1.028 \\
\cline { 2 - 4 } & Kepatuhan Pembayaran Pajak & .836 & 1.196 \\
\cline { 2 - 4 } & Layanan Samsat Keliling & .825 & 1.212 \\
\hline \multicolumn{2}{|c|}{ a. Dependent Variable: Penerimaan Pajak Kendaraan Bermotor } \\
\hline
\end{tabular}

Berdasarkan tabel di atas dapat dilihat bahwa seluruh variabel independen berkisar 1,028 sampai 1,212 lebih kecil dari 10 dan nilai tolerance seluruh variabel berkisar 0,825 sampai 0,972 lebih besar dari 0,1 maka dapat dikatakan tidak terjadi multikolinieritas pada seluruh variabel bebas.

c. Uji Heteroskedastisitas

Model regresi yang baik adalah tidak terjadi heteroskedastisitas, dengan kriteria hasil pengujian apabila nilai sig. $\mathrm{F}<0,05$ maka terjadi heteroskidasitas dan apabila nilai sig. $\mathrm{F}>0,05$ maka tidak terjadi heteroskedasitas. 


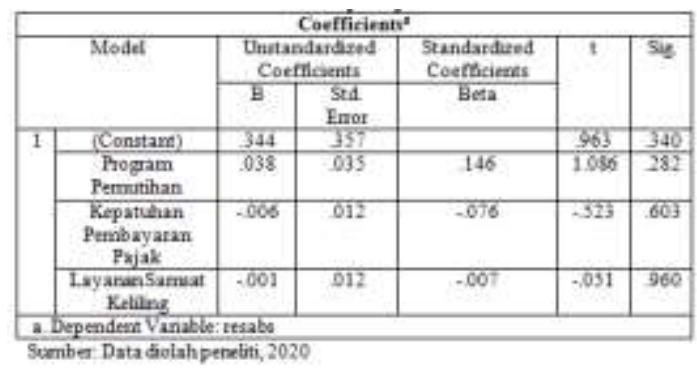

Dari tabel di atas diketahui bahwa nilai Sig. ketiga variabel independen lebih dari 0,05 yaitu berkisar 0,282 dan 0,960. Dikarenakan nilai Sig. lebih besar dari 0,05 maka dapat disimpulkan bahwa tidak terdapat heteroskedastisitas.

d. Uji Autokorelasi

Digunakan untuk mengestimasi model regresi terbebas dari autokorelasi. Hasil uji autokorelasi, dapat dilihat pada tabel Model Summary.

\begin{tabular}{|l|c|c|c|c|c|c|}
\hline \multicolumn{7}{|c|}{ Model Summary } \\
\hline Model & $\begin{array}{c}\text { Change Statistics } \\
\text { R Square } \\
\text { Change }\end{array}$ & $\begin{array}{c}\text { F } \\
\text { Change }\end{array}$ & df1 & df2 & $\begin{array}{c}\text { Sig. F } \\
\text { Change }\end{array}$ & Watson \\
\hline 1 & .194 & 4.424 & 3 & 55 & .007 & 2.132 \\
\hline
\end{tabular}

Sumber: Data diolah peneliti, 2020

Nilai DW hitung pada tabel diatas sebesar 2,132 lebih besar dari nilai $\mathrm{d}_{\mathrm{U}}=$ 1,6815 dan lebih kecil dari nilai $4-\mathrm{d}_{\mathrm{U}}=2,3185$ yang artinya hasil output yang didapat, $\mathrm{d}_{\mathrm{U}}(1,6815)<2,132<4-\mathrm{d}_{\mathrm{U}}(2,3185)$ berada pada daerah yang menunjukkan tidak ada terjadi autokorelasi.

\section{Analisis Regresi Linier Berganda}

Persamaan regresi linier berganda dalam penelitian ini adalah:

$\mathrm{Y}=0,637+0,159 \mathrm{X}_{1}+0,044 \mathrm{X}_{2}-0,016 \mathrm{X}_{3}$

Berdasarkan persamaan di atas, dapat diketahui bahwa kedua variabel independen yaitu Program Pemutihan $\left(\mathrm{X}_{1}\right)$ dan Kepatuhan Pembayaran Pajak $\left(\mathrm{X}_{2}\right)$ memberikan pengaruh signifikan terhadap Penerimaan Pajak Kendaraan Bermotor (Y) sebesar 0,203 $(0,159+0,044=0,203)$.

\section{Uji t}

Hasil pengujian dapat dilihat pada tabel Coefficients $^{a}$ dimana tabel ini menjelaskan informasi mengenai persamaan regresi tentang ada tidaknya pengaruh variabel independen terhadap variabel dependen secara parsial. 


\begin{tabular}{|c|c|c|c|c|c|c|c|c|}
\hline \multicolumn{9}{|c|}{ Coefficients $^{\mathrm{n}}$} \\
\hline \multirow{2}{*}{\multicolumn{2}{|c|}{ Model }} & \multicolumn{2}{|c|}{$\begin{array}{l}\text { Unstandardized } \\
\text { Coefficients }\end{array}$} & \multirow{2}{*}{$\begin{array}{c}\begin{array}{l}\text { Standardized } \\
\text { Coefficients }\end{array} \\
\text { Beta }\end{array}$} & \multirow[t]{2}{*}{$\mathrm{t}$} & \multirow[t]{2}{*}{ Sig. } & \multicolumn{2}{|c|}{$\begin{array}{l}\text { Collinearity } \\
\text { Statistics }\end{array}$} \\
\hline & & B & $\begin{array}{l}\text { Std. } \\
\text { Error }\end{array}$ & & & & Tolerance & VIF \\
\hline \multirow[t]{4}{*}{1} & (Constant) & .637 & .546 & & 1.166 & .249 & & \\
\hline & $\begin{array}{l}\text { Program } \\
\text { Pemutihan }\end{array}$ & .159 & .053 & .366 & 2.980 & .004 & .972 & 1.028 \\
\hline & $\begin{array}{l}\text { Kepatuhan } \\
\text { Pembayaran } \\
\text { Pajak }\end{array}$ & .044 & .019 & .314 & 2.370 & .021 & .836 & 1.196 \\
\hline & $\begin{array}{l}\text { Layanan } \\
\text { Samsat } \\
\text { Keliling }\end{array}$ & -.016 & .018 & -.118 & -.889 & 378 & .825 & 1.212 \\
\hline
\end{tabular}

Sumber: Data diolah peneliti, 2020

Berdasarkan tabel dapat diketahui pengaruh antara variabel independen Efektivitas Program Pemutihan $\left(\mathrm{X}_{1}\right)$, dan Kepatuhan Pembayaran Pajak $\left(\mathrm{X}_{2}\right)$, secara parsial atau individu terhadap variabel dependen yaitu Penerimaan PKB (Y) maka digunakan $t_{\text {hitung }} 2,980$ dan 2,370 lebih besar dari $t_{\text {tabel }} 2,001$. Sedangkan untuk variabel Layanan Samsat Keliling $\left(\mathrm{X}_{3}\right)$ nilai $\mathrm{t}_{\text {hitung }} 0,889<\mathrm{t}_{\text {tabel }} 2,001$.

\section{Uji F}

Hasil uji $\mathrm{F}$ yang menjelaskan informasi mengenai ada atau tidaknya pengaruh variabel independen terhadap variabel dependen secara simultan. Jika nilai Sig. < 0,05 dan nilai $\mathrm{F}$ hitung $>$ nilai $\mathrm{F}$ tabel maka ada pengaruh signifikan variabel bebas terhadap variabel terikatnya.

\begin{tabular}{|c|c|c|c|c|c|c|}
\hline \multicolumn{7}{|c|}{ ANOVA $^{\mathrm{a}}$} \\
\hline \multicolumn{2}{|c|}{ Model } & Sum of & $\mathrm{Df}$ & Mean & F & Sig. \\
\hline \multirow[t]{3}{*}{1} & $\begin{array}{l}\text { Regressio } \\
\mathrm{n}\end{array}$ & 2.524 & 3 & 841 & 4.424 & $.007^{\mathrm{b}}$ \\
\hline & Residual & 10.459 & 55 & .190 & & \\
\hline & Total & 12.983 & 58 & & & \\
\hline \multicolumn{7}{|c|}{ a. Dependent Variable: Penerimaan Pajak Kendaraan Bermotor } \\
\hline \multicolumn{7}{|c|}{$\begin{array}{l}\text { b. Predictors: (Constant), Layanan Samsat Keliling, Program Pemutihan, } \\
\text { Kepatuhan Pembayaran Pajak }\end{array}$} \\
\hline
\end{tabular}

Dari tabel di atas, diketahui nilai Sig. pada tabel nilainya 0,007 $<0,05$ sehingga dapat disimpulkan bahwa adanya pengaruh signifikan variabel independen Program Pemutihan $\left(\mathrm{X}_{1}\right)$, Kepatuhan Pembayaran Pajak $\left(\mathrm{X}_{2}\right)$ dan Layanan Samsat Keliling $\left(\mathrm{X}_{3}\right)$ secara simultan (bersamaan) terhadap variabel dependen Penerimaan Pajak Kendaraan Bermotor (Y).

\section{Interpretasi Data}

1. Hubungan Efektivitas Program Pemutihan terhadap Peningkatan Penerimaan PKB

Berdasarkan hasil pengujian $\mathrm{H}_{1}$ terdapat pengaruh Efektivitas Program Pemutihan terhadap Penerimaan PKB secara parsial diperoleh nilai signifikansi $0,004<$ alpha 0,05 . Hal ini menunjukkan bahwa program pemutihan dinilai efektif dalam meningkatkan penerimaan PKB di Kota Kediri. Hal ini sama dengan 
penelitian Collin dan Khairani (2019) yang mana pemutihan PKB berpengaruh positif terhadap peningkatan PKB.

2. Hubungan Tingkat Kepatuhan Pembayaran Pajak terhadap Peningkatan Penerimaan PKB

Berdasarkan hasil pengujian $\mathrm{H}_{2}$ terdapat pengaruh Kepatuhan Pembayaran Pajak terhadap Penerimaan PKB secara parsial diperoleh nilai signifikansi 0,021 < alpha 0,05. Hal ini menunjukkan bahwa tingkat kepatuhan pembayaran pajak berpengaruh positif signifikan terhadap penerimaan Pajak Kendaraan Bermotor. Hal ini juga sebanding dengan penelitian Collin dan Khairani (2019) yang mana kepatuhan pembayaran pajak berpengaruh positif terhadap peningkatan PKB.

3. Hubungan Layanan Samsat Keliling terhadap Peningkatan Penerimaan Pajak Kendaraan Bermotor

Berdasarkan hasil pengujian $\mathrm{H}_{3}$ terdapat pengaruh Layanan Samsat Keliling terhadap Penerimaan PKB secara parsial diperoleh nilai signifikansi $0,378>$ alpha 0,05. Hal ini menunjukkan bahwa layanan Samsat Keliling tidak berpengaruh signifikan terhadap penerimaan Pajak Kendaraan Bermotor. Hal ini tidak sama dengan penelitian Fatimah (2018), yang mana adanya Samsat Keliling berpengaruh secara signifikan terhadap penerimaan PKB.

4. Hubungan Efektivitas Program Pemutihan, Tingkat Kepatuhan Pembayaran Pajak, dan Layanan Samsat Keliling terhadap Peningkatan Penerimaan Pajak Kendaraan Bermotor

Berdasarkan hasil pengujian secara simultan, penelitian ini berhasil membuktikan adanya pengaruh secara simultan antara efektivitas program pemutihan, tingkat kepatuhan pembayaran pajak, dan layanan samsat keliling terhadap peningkatan penerimaan pajak kendaraan bermotor. Hal ini ditunjukkan oleh hasil perhitungan uji $\mathrm{F}$ dari variabel independen yang berpengaruh terhadap variabel dependen.

\section{KESIMPULAN}

Berdasarkan hasil analisis efektivitas program pemutihan berpengaruh terhadap penerimaan $\mathrm{PKB}$, program pemutihan dinilai sangat efektif dalam meningkatkan penerimaan PKB. Dengan adanya program pemutihan Wajib Pajak dinilai sangat antusias dengan adanya program pemutihan yang dilaksanakan tiap tahunnya karena dapat meringankan beban denda administrasi bagi Wajib Pajak yang terlambat melakukan pembayaran PKB. Faktor lain yang dapat mempengaruhi penerimaan $\mathrm{PKB}$, yaitu tingkat kepatuhan Wajib Pajak dalam melaksanakan kewajiban perpajakannya. Semakin tinggi tingkat kepatuhan Wajib Pajak maka semakin meningkat pula penerimaan PKB. Dengan adanya berbagai 
gerai pembantu Samsat diharapkan Wajib Pajak dapat melakukan pembayaran dengan tepat waktu. Pembayaran PKB tahunan dapat dilakukan di gerai-gerai pembantu Samsat seperti Samsat Keliling. Dengan adanya Samsat Keliling, diharapkan dapat memudahkan Wajib Pajak dalam membayar Pajak Kendaraan Bermotornya. Namun, Samsat Keliling ini kurang dijangkau oleh Wajib Pajak pada penelitian ini sehingga Layanan Samsat Keliling dinilai kurang efektif dalam meningkatkan penerimaan Pajak Kendaraan Bermotor karena ada beberapa opsi pembayaran lain yang dapat dilakukan oleh Wajib Pajak

\section{DAFTAR PUSTAKA}

Collin, N., \& Khairani, S. (2019). Pemutihan, Kepatuhan Pembayaran, Pajak Kendaraan Bermotor. 05, 1-10.

Fatimah, N. (2018). Analisis Pengaruh Samsat Keliling Terhadap Peningkatan Penerimaan Pajak Kendaraan Bermotor di Kabupaten Purwakarta.

Ghozali, Imam. (2016). Aplikasi Analisis Multivariete dengan Program IBM SPSS 23 (Edisi 8). Cetakan ke VIII. Semarang: Badan Penerbit Universitas Diponegoro.

Keputusan Menteri Keuangan. Nomor 544/KMK.04/2000 tentang Kriteria Wajib Pajak Yang Dapat Diberikan Pengembalian Pendahuluan Kelebihan Pembayaran Pajak, (2020).

Mahmudi. (2015). Manajemen Kinerja Sektor Publik (Ketiga). Unit Penerbit dan Percetakan.

Peraturan Gubernur No. 55 Tahun 2019 tentang Pembebasan Pajak Daerah untuk Rakyat Jawa Timur Tahun 2019, (2019).

Peraturan Presiden Republik Indonesia Nomor 5 Tahun 2015 Tentang Penyelenggaraan Sistem Administrasi Manunggal Satu Atap Kendaraan Bermotor, (2015). 